The Engineer and Society 
Other Macmillan titles of related interest

The Management of Manufacturing Systems

J.D. Radford and D.B. Richardson

Production Engineering Technology, second edition

J.D. Radford and D.B. Richardson 


\title{
The Engineer and Society
}

An Introduction to

Engineering Management

\author{
J.D. Radford \\ B.Sc. (Eng.), F.I.Prod.E., M.I. Mech.E.
}

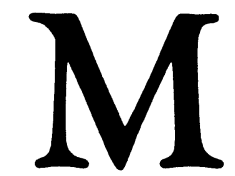

MACMILLAN 
(C) J.D. Radford 1984

Softcover reprint of the hardcover 1st edition 1984

All rights reserved. No part of this publication

may be reproduced or transmitted, in any form or by

any means, without permission.

First published by

Higher and Further Education Division

MACMILLAN PUBLISHERS LTD

London and Basingstoke

Companies and representatives

throughout the world

ISBN 978-0-333-35816-0 ISBN 978-1-349-17506-2 (eBook)

DOI 10.1007/978-1-349-17506-2

British Library Cataloguing in Publication Data

Radford, Dennis

The engineer and society.

1. Engineering Great Britain-Management

I. Title

$620^{\prime} .0068$

TA190 


\section{Contents}

Preface vi

Acknowledgements vii

1 Development of Engineering Technology 1

2 Industrial Organisations and their Environment 33

3 Management Organisation $\quad 44$

$\begin{array}{lll}4 \text { Communication } & 60\end{array}$

5 Marketing $\quad 70$

$\begin{array}{lll}6 & \text { The Engineer and the Law } & 87\end{array}$

$\begin{array}{llr}7 & \text { Management of People } & 103\end{array}$

8 Financial Management 123

9 Design of Manufacturing Systems 153

10 Operation of Manufacturing Systems $\quad 169$

$\begin{array}{ll}\text { Index } & 203\end{array}$ 


\section{Preface}

This book has been written because there is no other single text that attempts to help students who are preparing for examinations in 'The Engineer in Society'. Also it is hoped that the book will be of use to students following a variety of engineering courses in which there is some management content.

The text is based on lecture notes used by the author in teaching 'The Engineer in Society' to students reading for degrees in mechanical engineering.

Many may feel that this book is too brief, but its brevity is intentional and designed to keep the price within the book-buying budgets of most students.

Engineers have been referred to in the masculine gender. This was done to avoid the form him/her or he/she; it in no way implies a refusal to recognise the growing importance of women in the profession.

J.D. Radford 


\section{Acknowledgements}

I should like to express my appreciation to all those who have assisted in the preparation of this book; in particular my colleagues Mr Don Richardson for his helpful criticism and Mrs Brenda Foster and Miss Karen Harman for their help in typing the manuscript. 